1 Skakkebaek NE. Possible carcinoma in situ of the testis. Lancet 1972;ii:516-7.

2 Anonymous. Testisticular biopsy for early detection of testicular tumour [Editorial]. Br Med $\mathcal{J}$ 1980;1280:426-7

3 Rorth M, Grigor KM, Giwercman A, Dawgaard G, Skakkebaek N, eds. Carcinoma-in-situ and testis cancer: biology and treatment. Proceedings of $a$ Workshop on Testis Cancer held in Copenhagen 1986. Oxford: Blackwell Scientific Publications, in press.

4 Skakkebaek NE, Bethelsen JG, Giwercman A, Muller J. Carcinoma-in-situ of the testis: possible origin from genocytes and precursor of all types of germ cell tumours except spermatocytoma. Int $\mathcal{7}$ Androl (suppl 7), in press.

5 Muller J, Skakkebaek NE, Nielsen OH, Graem N. Cryptorchidism and testis cancer. Cancer 1984;54:629-34.

Stein NA, Jain R. Testicular intratubular origin of choriocarcinoma. Urology 1982;20:296-7.

7 Skakkebaek NE, Berthelsen JG, Muller J. Carcinoma-in-situ of the undescended testis. Urol Clin North Am 1982;9:377-85.

8 Berthelsen JG, Skakkebaek NE. Distribution of carcinoma in situ in the testis from infertile men. Int 7 Androl $1981 ; 4$ (suppl) $): 172-84$

Krabbe S, Skakkebaek NE, Berthelsen JG, et al. High incidence of undetected neoplasia in maldescended testes. Lancet 1979;i:999-1000.

10 Pryor JP, Cameron KM, Chilton CP, et al. Carcinoma in situ in testicular biopsies from men presenting with infertility. $B r \mathcal{F}$ Urol 1983;55:780-4

11 West AB, Butler MR, Fitzpatrick J, O'Brien A. Testicular tumors in subfertile men: report of 4 cases with implications for management of patients presenting with infertility. $\mathcal{J}$ Urol 1985;133:1-9.

12 Skakkebaek NE. Carcinoma in situ of the testis: frequency and relationship to invasive germ cell tumours in infertile men. Histopathology 1978;2:157-70.

13 Nuesch-Bachmann IH, Hedinger C. Atypische spermatogonien als Prakanzerose. Schweiz Med Wochenschr 1977;107:795-801.

14 Romanenko AM, Persidskii IuV. Znachenie atipichnykh polovykh kletok $\mathbf{v}$ gistogeneze germinativnykh opukholei iaichka; The importance of atypical cells in histogenesis of germ cell germinativnyk opukholei iaichka, The importance of atypical cells 8 .

15 Williams TR, Bendler H. Carcinoma in situ of the ectopic testis. F Urol 1977;117:610-2.

16 Ishida $\mathrm{H}$, Isurugi $\mathrm{K}$, Nijijima T, et al. Carcinoma in situ germ cells and subsequent development of an invasive seminoma in a hyperprolactinaemic man. Int $\mathcal{f}$ Androl 1983;6:229-34.

17 Muller J, Skakkebaek NS. Testicular carcinoma in situ in children with the androgen insensitivity suller J, Skakkebaek NS. Testicular carcinoma in situ in children with the androme (testicular feminsation syndrome). $B r$ Med $\mathcal{F} 1984 ; 288: 1419-20$.
syndrom

18 Peckham MJ, Barret A, Husband JE, Hendry WF. Orchiectomy alone in testicular stage 18 nonseminomatous germ cell tumours. Lancet 1977; ii:678-80.

19 Chilvers C, Pike MC, Forman D, Fogelman K, Wadsworth MEJ. Apparent doubling of frequency of undescended testis in England and Wales in 1962-81. Lancet 1984;ii:330-2.

20 Hargreave TB, Elton RA, Webb Jennifer A, Busuttil A, Chisholm GD. Maldescended testes and fertility: a review of 68 cases. Br $\mathcal{F}$ Urol 1984;56:734-9.

21 Pike MC, Chilvers C, Peckham MJ. Effect of age at orchidopexy on risk of testicular cancer. Lancet 1986; : 1246-8.

22 Thornhill JA, Conroy RM, Kelly DG, Walsh A, Fennelly JJ, Fitzpatrick JM. Public awareness of testicular cancer and the value of self examination. $\mathrm{Br}$ Med $\mathcal{f}$ 1986;293:480-1.

23 von der Maase H, Giwercman A, Skakkebaek NE. Radiation treatment of carcinoma in situ of testis. Lancet 1986;: $624-5$.

\section{The decline in the teaching of legal medicine}

The teaching of legal medicine and ethics in British medical schools is "barely sufficient for the needs of today" and is declining, conclude Knight and Thompson in a recent review. ${ }^{1}$ Replies from the deans of 19 medical schools showed that the amount of time spent lecturing on legal medicine varied from three to 39 hours, and eight deans reported that the amount of teaching time had fallen since 1976. About two thirds of 75 students and 77 recently qualified doctors who answered questionnaires thought that the teaching of legal medicine was inadequate. The most powerful indictments came from coroners: "I am amazed and appalled at the lack of knowledge of many doctors relating to their responsibilities in regard to the types of death which require notification to the coroner"; "My experience is that the average doctor does not know what to do when faced with the abnormal or suspicious death."

The educational committee of the General Medical Council and the advisory committee on medical training of the Commission of the European Community have both stated that newly qualified doctors should have an adequate knowledge of the laws concerning medical practice. The BMA annual representative meeting in Scarborough this year resolved that the GMC should instruct individual medical schools to have an identifiable and substantial part of the undergraduate medical curriculum devoted to the ethical and legal aspects of medical practice. ${ }^{2}$ Knight and Thompson's results suggest that many do not.

The decline in medicolegal instruction to students can be traced back to the time when a separate examination in forensic medicine was abolished in the final qualifying examination. Since then the time devoted to this instruction has been eroded by the many specialties that have mushroomed in the past 30 years. Medical students attend courses on many subjects that may be of little or no practical value to them after qualification, but no matter what branch of medicine or surgery the graduate enters he will always have to face medicolegal problems. If he is in general practice these may occur daily.

Many doctors are ignorant even about death certification. In some hospitals the junior doctor is told what he should put on a death certificate by a clerk in the office or by the mortuary superintendent. Little wonder that relatives are upset by having to delay funeral arrangements because the registrar of births and deaths has been unable to accept the certified cause of death. Both junior and senior doctors are often unaware of which deaths should be referred to the coroner, although lists of such deaths are readily available from the medical defence and protection societies and from reference to any standard book on forensic medicine. The list also appears in the preface to each book of death certificates.

What are the basic medicolegal requirements of the medical student? He should know the legal responsibility of correct death certification and the deaths that should be referred to the coroner. He should be able to write medicolegal reports for the coroner and courts that can be understood by non-medical people and are devoid of ambiguities. He must know his responsibilities under the various drugs and human tissues acts, and he must be able to conduct a medicolegal examination in cases of alleged assaults and of sexual offences. This requires a knowledge of patterns of injury and the ability to separate deliberate from accidental wounds. He must also understand confidentiality and medical ethics.

An ad hoc committee of medicolegal experts representing the countries of the European Community met recently in Seville to discuss the harmonisation of medicolegal teaching to both undergraduates and postgraduates. This harmonisation is required to fulfil the provisions of the Treaty of Rome on the free circulation of professional men throughout the community. The final report, which will be presented to the European Parliament in Strasburg, recommends that undergraduates receive a minimum of 60 hours medicolegal instruction during their final two clinical years. The student should be required then to pass an examination to show that he had acquired an adequate knowledge of medicolegal matters before starting to practise medicine.

Medicolegal departments on the Continent often cover all aspects of forensic medicine and science, including psychiatry and assessment of disabilities (insurance medicine), which are dealt with by other departments in Britain. Nevertheless, even if psychiatry, insurance medicine, industrial medicine, and laws relating to drugs are dealt with by other departments, an undergraduate course of some 30-40 lectures and demonstrations in legal medicine would still be essential to attain the basic European standard. Unless this is done medicolegal standards will continue to decline-to the detriment of the community.

A KeIth MaNT

Emeritus Professor of Forensic Medicine,

Guy's Hospital,

London SE1 9RT

1 Knight B, McKim Thompson I. The teaching of legal medicine in British medical schools. Med Educ 1986;20:246-58.

2 Anonymous. Briefing: from the annual representatives' meeting [Editorial.] BMA News Review 1986;12(Sept):33. 